\title{
A Review on Antimicrobial Activity of Mushroom (Basidiomycetes) Extracts and Isolated Compounds
}

\author{
Authors \\ Maria José Alves ${ }^{1,2,3,4}$, Isabel C. F. R. Ferreira ${ }^{3}$, Joana Dias ${ }^{4}$, Vânia Teixeira ${ }^{4}$, Anabela Martins ${ }^{3}$, Manuela Pintado \\ Affiliations \\ ${ }^{1}$ CBQF-Escola Superior de Biotecnologia, Universidade Católica Portuguesa Porto, Porto, Portugal \\ ${ }^{2}$ Centro Hospitalar de Trás-os-Montes e Alto Douro-Unidade de Chaves, Chaves, Portugal \\ ${ }^{3}$ CIMO-Escola Superior Agrária, Instituto Politécnico de Bragança, Campus de Santa Apolónia, Bragança, Portugal \\ ${ }^{4}$ Escola Superior de Saúde, Instituto Politécnico de Bragança, Bragança, Portugal
}

Key words

- mushrooms

- Basidiomycetes

- antimicrobials

- gram-positive bacteria

- gram-negative bacteria received July 3,2012

revised August 8, 2012

accepted August 22, 2012

Bibliography

Dol http://dx.doi.org/

10.1055/s-0032-1315370

Published online September 21,

2012

Planta Med 2012; 78:

1707-1718 @ Georg Thieme

Verlag KG Stuttgart · New York ·

ISSN 0032-0943

\section{Correspondence}

Prof. Isabel C. F. R. Ferreira,

PhD

Instituto Politécnico de Bragança

Campus de Santa Apolónia,

apartado 1172

5301-855 Bragança

Portugal

Phone: + 351273303219

Fax: + 351273325405

iferreira@ipb.pt

\section{Abstract}

$\nabla$

Despite the huge diversity of antibacterial compounds, bacterial resistance to first-choice antibiotics has been drastically increasing. Moreover, the association between multiresistant microorganisms and nosocomial infections highlight the problem, and the urgent need for solutions. Natural resources have been exploited in the last years and among them, mushrooms could be an alternative source of new antimicrobials. In this review, we present an overview of the antimicrobial properties of mushroom extracts and highlight some of the active compounds identified, including low- and high-molecular weight (LMW and HMW, respectively) compounds. LMW compounds are mainly secondary metabolites, such as sesquiterpenes and other terpenes, steroids, anthraquinones, benzoic acid derivatives, and quinolines, but also primary metabolites such as oxalic acid. HMW compounds are mainly peptides and proteins. Data available from the literature indicate a higher antimicrobial activity of mushroom extracts against gram-positive bacteria. Among all the mushrooms, Lentinus edodes is the most studied species and seems to have a broad antimicrobial action against both grampostive and gram-negative bacteria. Plectasin peptide, obtained from Pseudoplectania nigrella, is the isolated compound with the highest antimi-

\section{Introduction}

\section{$\nabla$}

\section{Mushroom bioactivity}

For a long time, mushrooms have been playing an important role in several aspects of human activity. Edible mushrooms, for example, are used extensively in cooking and make up part of low-calorie diets. Mythology is extensively garnished by mushrooms and is typically associated with gnomes, fairies, and other fairytale personages. crobial activity against gram-positive bacteria, while 2-aminoquinoline, isolated from Leucopaxillus albissimus, presents the highest antimicrobial activity against gram-negative bacteria.

\section{Abbreviations \\ $\nabla$}

CSAP: $\quad$ Cordyceps sinensis antibacterial protein

CFU: colony forming unities

ERSP: erythromycin-resistant Streptococcus pyogenes

HMW: high-molecular weight compounds

$\mathrm{IC}_{50}$ : concentration inhibiting $50 \%$ of the growth

IZD: internal zone diameter

LMW: low-molecular weight compounds

M: mycelium

MIC: minimal inhibitory concentration

MRSA: methicillin-resistant Staphylococcus aureus

MRSE: methicillin-resistant Staphylococcus epidermidis

PABA: para-aminobenzoic acid

PRSP: $\quad$ penicillin-resistant Streptococcus pneumonia

VREF: Vancomycin-resistant Enterococcus faecium

The psychedelic and consciousness expansion properties of some species have pushed mushrooms to become part of some religions. Even toxic mushrooms have found a place of relevance, because of the uniqueness of their compounds that evolved naturally as a protection against consumption [1].

Wild and cultivated mushrooms contain a huge diversity of biomolecules with nutritional [2] and/or medicinal properties [3-5]. Due to these 
properties, they have been recognized as functional foods, and as a source for the development of medicines and nutraceuticals. Fruiting bodies, mycelia, and spores accumulate a variety of bioactive metabolites with immunomodulatory, cardiovascular, liver protective, antifibrotic, anti-inflammatory, antidiabetic, antiviral, antioxidant, antitumor, and antimicrobial properties [3-14].

The frequent use of mushrooms is based on three main assumptions: first, they are used as part of a regular diet for their nutritional value (since they are rich in water, minerals, proteins, fibers, and carbohydrates, and are low-caloric foods due to a low content in fat [2]); secondly, fruiting bodies are also appreciated for their delicacy (they are palatability enhancers of flavor and aroma when associated to other foods); and thirdly, mushrooms are widely used for medicinal purposes. Their pharmacological action and therapeutic interest in promoting human health have been known for thousands of years $[5,15,16]$.

In particular, mushrooms could be a source of natural antibiotics, which can be LMW and HMW, respectively, compounds. LMW compounds are mainly secondary metabolites such as sesquiterpenes and other terpenes, steroids, anthraquinone and benzoic acid derivatives, and quinolines, but also primary metabolites such as oxalic acid ( Fig. 1). HMW compounds mainly include peptides and proteins.

It is estimated that there are about 140000 species of mushrooms on earth, and of these only 22000 are known and only a small percentage (5\%) has been investigated. Therefore, there is

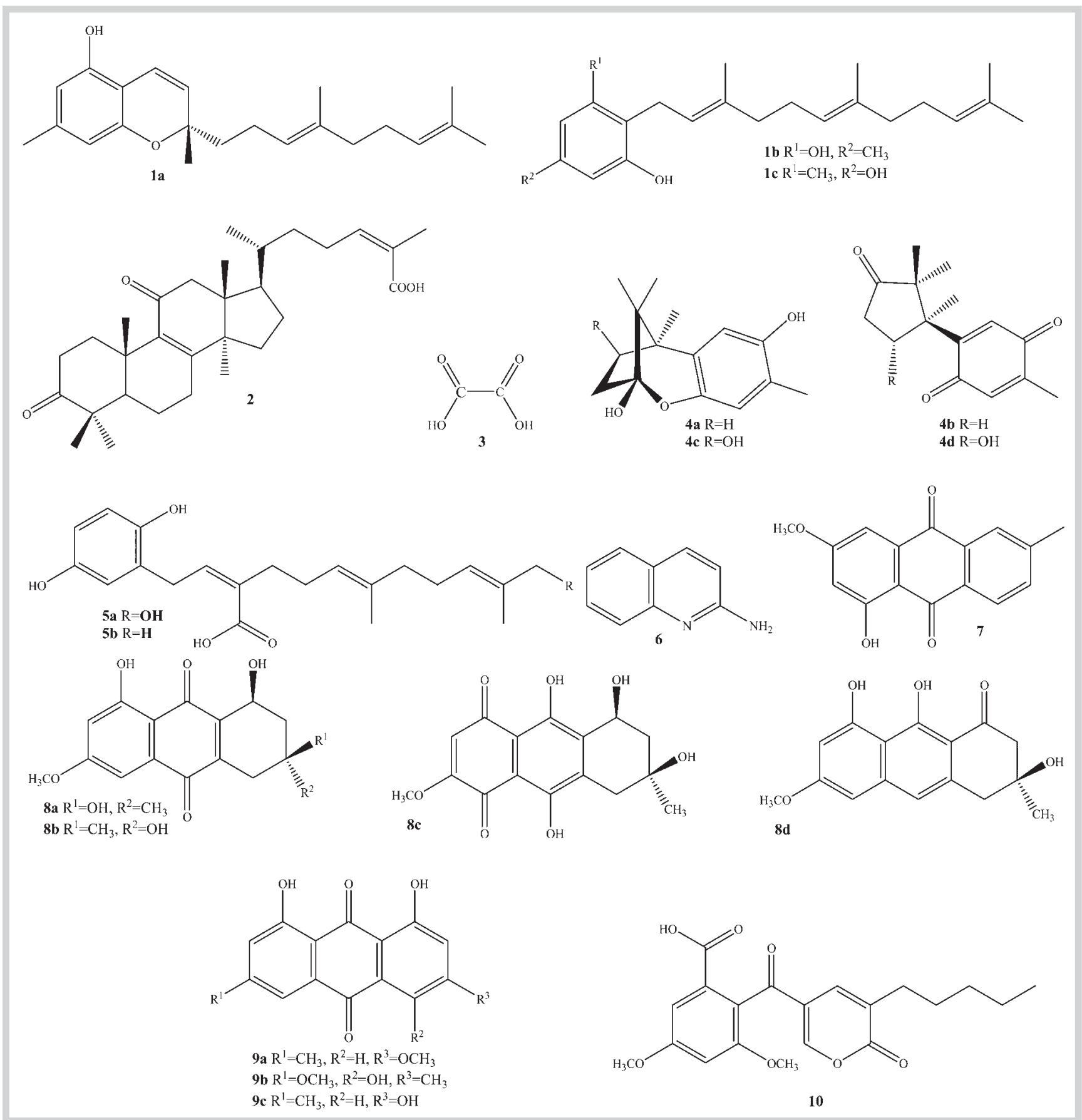

Fig. 1 Chemical structure of the low-molecular weight (LMW) compounds with antimicrobial potential found in mushrooms. 
much to explore about mushroom properties and potential applications [4].

\section{Bacteria and drug discovery}

The development of antibiotics has been one of the most important scientific achievements of the last seventy years. These compounds act in several ways, by interfering in metabolic processes or in the organism structures [17]. The mechanism of action is mostly related with interferences in the synthesis of the cell wall, modification of plasmatic membrane permeability, interferences in chromosome replication, or in protein synthesis [18]. The cell wall is responsible for the shape and rigidity of bacterial cells, acting as an osmotic barrier [19]. The peptidoglycan content in the cell wall varies between $10 \%$ and $60 \%$ for gram-negative and gram-positive bacteria, respectively $[20,21]$.

Antiparietal antibiotics act in one of the phases of peptidoglycan synthesis, being classified according to that phase. Phosphomycin, D-cycloserine, glycopeptides (bacitracin, vancomycin, teicoplanin), and beta-lactams (penicillins, cephalosporins, carbapenemics, monobactamics) are some examples of this group [22].

Otherwise, other antibiotics such as ascolistin and daptomycin act at the cell membrane level. Aminoglycosides and tetracyclines, macrolides, oxazolidines, quinupristin and dalfopristin, clindamycin, and chloramphenicol inhibit protein synthesis by interfering with $30 \mathrm{~s}$ or $50 \mathrm{~s}$ ribosomal subunits. Quinolones, rifampicin, and metronidazol inhibit nucleic acid synthesis. Sulfonamides and trimetoprim are antimetabolic antibiotics that inhibit the metabolic chain of PABA, essential to cell growth [23].

Despite the huge diversity of antibacterial compounds, bacterial resistance to first-choice antibiotics has been drastically increasing. Some examples are microorganisms such as Klebsiella spp. and Escherichia coli, which produce broad-spectrum beta-lactamase or present resistance to third-generation cephalosporins. Other examples include MRSA, Enterococcus spp., which is resistant to vancomycin [24,25], Acinetobacter spp. with an increasing resistance to carbapenems and colistin [26], and Pseudomonas spp., which is resistant to aminoglycosides, carbapenemics. and/ or cephalosporins [24].

Diseases that were easily healed are nowadays becoming a serious problem due to emergent antibiotic resistance $[27,28]$. The association between multiresistant microorganisms and hospital infections certainly highlights this problem and the urgent need for solutions [29]. In 2010, the World Health Organization advised all countries to implement control procedures for the propagation of drug multiresistant bacteria, highlighting the risks associated to the absence of alternative therapies against those microorganisms [30].

Therefore, the research of new antimicrobial substances effective against pathogenic microorganisms resistant to current drugs is crucial. New groups of organisms, such as marine, have been increasingly explored in the last years, and among them, mushrooms could be an alternative source for new antimicrobials. In this review, we provide an overview about the antimicrobial properties of mushroom extracts and highlight selected compounds. The databases searched were Medline (1980 to March 2012) and Web of Science (2001 to March 2012) including scientific articles and conference proceedings. Search terms were: "mushrooms", "antimicrobial activity", and "antimicrobials". An exhaustive literature search was performed, but only mushroom extracts and isolated compounds with positive results were included.

\section{Antimicrobial Activity Against Gram-Positive Bacteria} $\nabla$

\section{Methodologies}

Different methodologies have been used to assess antimicrobial activity of mushroom extracts and compounds, including the microdilution method, the disk diffusion method, the agar streak dilution method based on radial diffusion, and a method with the incorporation of the extract in the culture medium and further determination of colonies. Therefore, the results for antimicrobial activity are expressed in different unities ( 0 Tables $\mathbf{1}$ and 2 ).

The microdilution method comprises microdilutions of the extract in liquid medium using microplates to determine MIC or $\mathrm{IC}_{50}$ values. In the disk difusion method, the extract is incorporated in disks at different concentrations, and the halo of growth inhibition is determined and represented by IZD (internal zone diameter) values. The agar streak dilution method based on radial diffusion is most widely used in extracts and implies the extract application in circular holes made in solid medium. The result might be expressed in IZD or MIC values. Regarding the fourth method, the extract is incorporated in the culture medium and then $\mathrm{CFU}$ are determined.

\section{Mushroom extracts with antimicrobial activity}

Numerous mushroom extracts have been reported as having antimicrobial activity against gram-positive bacteria ( 0 Table $\mathbf{1}$ ). Agaricus bisporus, the most cultivated mushroom in the world, should be highlighted. Its methanolic extract revealed MIC= $5 \mu \mathrm{g} / \mathrm{mL}$ against Bacillus subtilis, even lower than the standard ampicillin ( $\mathrm{MIC}=12.5 \mu \mathrm{g} / \mathrm{mL})$ [31], and also showed activity against Bacillus cereus, Micrococcus luteus, Micrococcus flavus, Staphylococcus aureus, and Staphylococcus epidermidis [15,32, 33]. Other Agaricus species have also demonstrated antimicrobial activity. Agaricus bitorquis and Agaricus essettei methanolic extracts showed an inhibitory effect upon all the tested gram-positive bacteria [15]. Agaricus silvicola methanolic extract also revealed antimicrobial properties against Bacillus cereus (MIC= $5 \mu \mathrm{g} / \mathrm{mL}$ ), Bacillus subtilis (MIC $=50 \mu \mathrm{g} / \mathrm{mL}$ ), and against Staphylococcus aureus (MIC $=5 \mu \mathrm{g} / \mathrm{mL}$ ), lower than the standard ampicillin (MIC $=6.25 \mu \mathrm{g} / \mathrm{mL}$ ) [31]. The mycelium of Agaricus cf. nigrecentulus and Tyromyces duracinus (ethyl acetate extracts) showed activity only against Staphylococcus saprophyticus [34].

The ethanolic extracts of Armillaria mellea mycelium showed an antibacterial effect against Sarcina lutea; however, no activity was observed upon other gram-positive bacteria [35]. However, the ethanolic extract of their fruiting bodies showed broad-spectrum antimicrobial activity [36].

The most studied mushroom of the genus Boletus is Boletus edulis. Its methanolic mushroom showed lower antimicrobial activity than other species studied by Ozen et al. [32]. Nevertheless, Barros et al. [31] reported an MIC $=5 \mu \mathrm{g} / \mathrm{mL}$ against Staphylococcus aureus, lower than ampicillin ( $\mathrm{MIC}=6.25 \mu \mathrm{g} / \mathrm{mL}$ ).

Cantharellus cibarius methanolic extract demonstrated good activity against Bacillus subtilis and Staphylococcus aureus [31,32, 37]. This mushroom also showed activity against Bacillus cereus in some studies $[32,37]$, but it was not so effective in another report [31], which could be related to the different methodologies used to evaluate antimicrobial activity.

Clitocybe alexandri methanolic extract presented significant activity against Bacillus subtilis and Micrococcus luteus [38]. Kalyoncu et al. [36] tested antimicrobial activity of chloroform and ethanolic extracts from Clitocybe geotropa, the latter showing asignificant capacity against Bacillus cereus. 


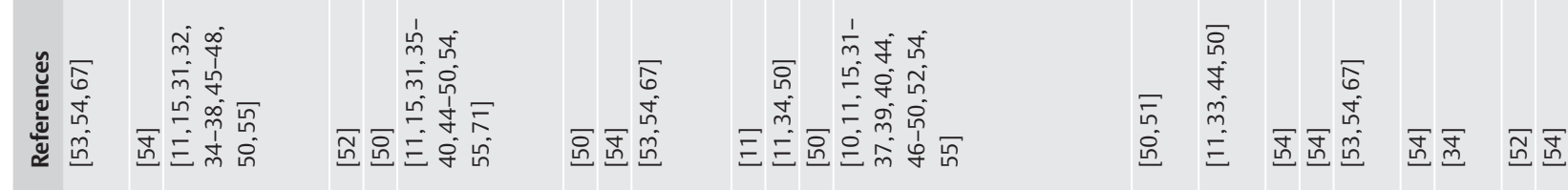

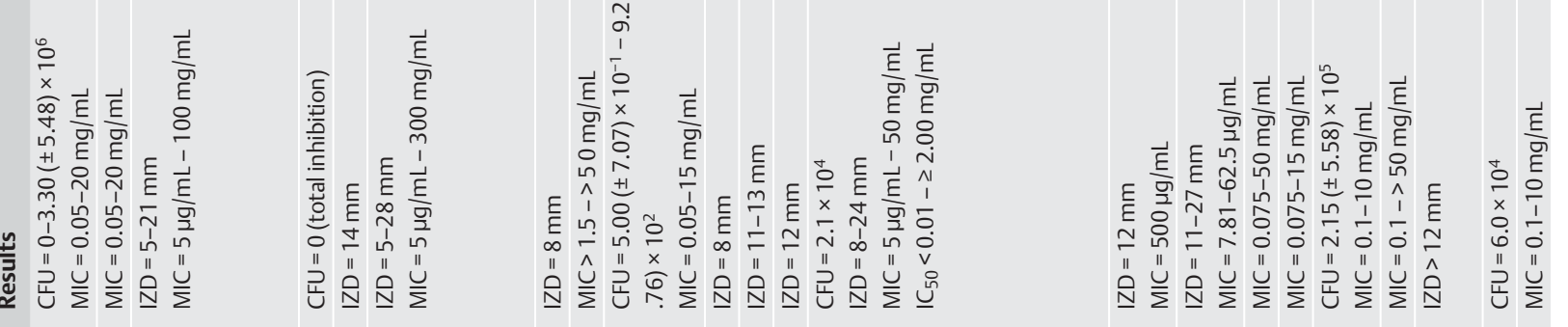

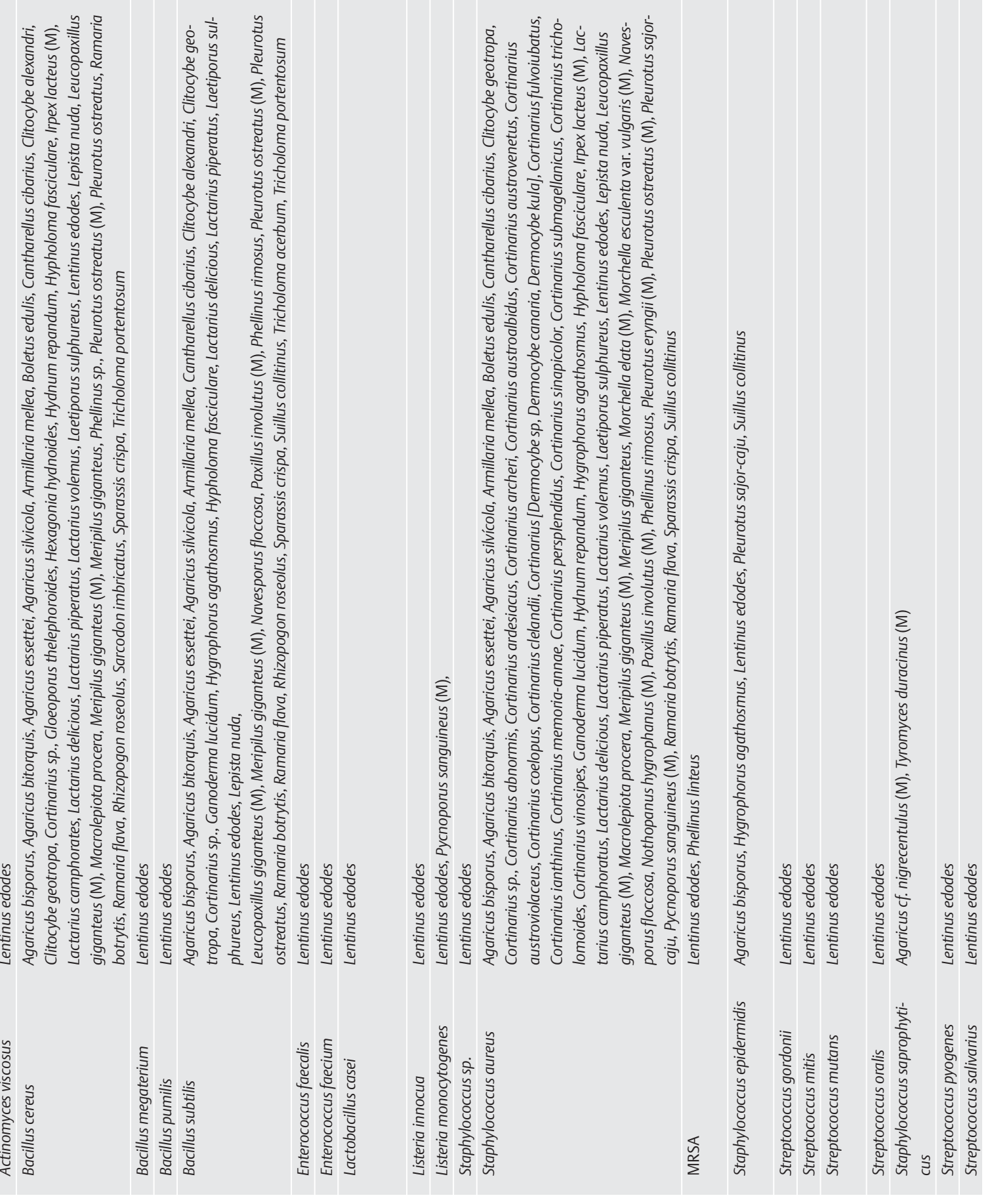




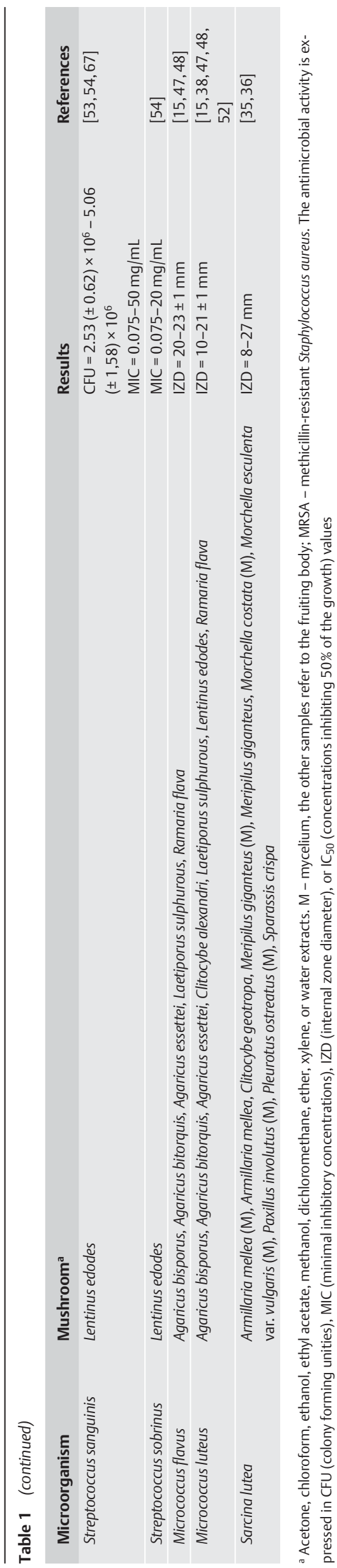

The genus Cortinarius is one of the most diverse genera of mushrooms. Ethyl acetate extracts of $C$. ardesiacus, C. archeri, C. atrosanguineus, C. austrovenetus, C. austroviolaceus, C. coelopus, C. [Dermocybe canaria], C. clelandii, C. [D. kula], C. memoria-annae, C. persplendidus, C. sinapicolor, C. vinosipes, and 47 other collection samples not identified to the species level, exhibited $\mathrm{IC}_{50}$ values of $\leq 0.09 \mathrm{mg} / \mathrm{mL}$ against Staphylococcus aureus [10]. However, in a study reported by Ozen et al. [32], Cortinarius sp. methanolic extracts showed lower activity against Staphylococcus aureus. This demonstrates the effect of solvent extraction in the type and concentration of compounds present in the final extract and, consequently, the spectrum of antimicrobial activity.

Ganoderma lucidum is one of the most famous traditional medicinal mushrooms. Various extracts have been found to be equally effective when compared to gentamycin sulphate, the acetone extract being the most effective. This mushroom had moderate inhibition against Bacillus subtilis and Staphylococcus aureus for any extract [39], but in the study reported by Sheena et al. [40], its methanolic extract showed poor antimicrobial activity. Other authors described the capacity of the aqueous extract to inhibit 15 types of gram-positive and gram-negative bacteria, with the highest inhibition exhibited against Micrococcus luteus [41].

Ethyl acetate extracts of Phellinus sp., Gloeoporus thelephoroides, and Hexagonia hydnoides inhibited Bacillus cereus growth, while the same extract of Nothopanus hygrophanus mycelium presented inhibitory activity against Listeria monocytogenes and Staphylococcus aureus. Irpex lacteus mycelium extract was the most effective, presenting a broad spectrum of activity [34].

The antimicrobial activity of Pycnoporus sanguineus has been known since 1946, when Bose isolated poliporin, a compound active against gram-positive and gram-negative bacteria and without toxicity in experimental animals. Rosa et al. reported inhibition against Listeria monocytogenes and Staphylococcus aureus [34]. Smânia et al. [42,43] showed that this mushroom produces cinnabarine, an orange pigment active against Bacillus cereus, Staphylococcus aureus, Leuconostoc mesenteroides, Lactobacillus plantarum, and several Streptococcus spp. Cinnabarine was more active against gram-positive than gram-negative bacteria [34]. The chloroform extract of Hygrophorus agathosmus and dichloromethane of Suillus collitinus were active against all the tested gram-positive bacteria. The highest antibacterial activity was seen in the extract of H. agathosmus against Staphylococcus epidermidis and Bacillus subtilis, with MIC values $7.81 \mu \mathrm{g} / \mathrm{mL}$ lower than the reference antibiotic streptomycin (MIC $=15.62 \mu \mathrm{g} / \mathrm{mL}$ ). MIC values $(15.62 \mu \mathrm{g} / \mathrm{mL})$ against Staphylococcus aureus were equal to the ones of streptomycin. Suillus collitinus showed MIC values much higher than the standard [44].

One nonedible mushroom, Hypholoma fasciculare (methanolic extract), presented high antimicrobial activity against gram-positive bacteria, namely Bacillus cereus, Bacillus subtilis, and Staphylococcus aureus [37].

All the tested gram-positive bacteria were susceptible to methanolic extracts of Lactarius species and Tricholoma portentosum $[32,45,46]$. Among Lactarius species (L. piperatus, L. camphorates, L. volemus, L. delicious), L. camphoratus methanolic extract was the one with greater antimicrobial activity [32]. Methanolic extracts of Ramaria botrytis and the ethanolic extract of Ramaria flava inhibited the growth of gram-positive bacteria better than gram-negative bacteria [47]. The antimicrobial effect of the ethanolic extract of Laetiporus sulphureus was tested by Turkoglu et al. [48] and strongly inhibited the growth of the gram-positive 
Table 2 Mushroom compounds with antimicrobial activity against gram-positive bacteria.

\begin{tabular}{|c|c|c|c|}
\hline Microorganism & Compound (mushroom) & Results & $\begin{array}{l}\text { Refer- } \\
\text { ences }\end{array}$ \\
\hline Bacillus cereus & $\begin{array}{l}\text { Confluentin (1a), Grifolin (1b) and Neogrifolin (1c) (Albatrellus flettii); 3,11-Dioxola- } \\
\text { nosta-8,24(Z)-diene-26-oic acid (2) (Jahnoporus hirtus); Oxalic acid (3) (Lentinus } \\
\text { edodes M); Proteins and peptides: Plectasin (Pseudoplectania nigrella) }\end{array}$ & $\begin{array}{l}\mathrm{IZD}=17 \mathrm{~mm} \\
\mathrm{MIC}=10 \mu \mathrm{g} / \mathrm{mL}-\geq 128 \mathrm{mg} / \mathrm{L}\end{array}$ & $\begin{array}{l}{[56,59,} \\
63]\end{array}$ \\
\hline Bacillus subtilis & $\begin{array}{l}\text { Peptides: Peptaibol Boletusin, Peptaibol Chrysospermin } 3 \text { and Peptaibol Chryso- } \\
\text { spermin } 5 \text { (Boletus spp.); Protein (Cordyceps sinensis); Enokipodins A, B, C and D } \\
\text { (4a-d) (Flammulina velutipes M); Ganomycin A and B (5a, b) (Ganoderma pfeifferi) }\end{array}$ & $\begin{array}{l}\mathrm{MIC}>100000 \mathrm{~g} / \mathrm{L} \\
\mathrm{IZD}=11-28 \mathrm{~mm}\end{array}$ & $\begin{array}{l}{[57,58,} \\
61,64]\end{array}$ \\
\hline Bacillus thuringiensis & Plectasin (Pseudoplectania nigrella) & $\mathrm{MIC}=0.5 \mathrm{mg} / \mathrm{L}$ & [63] \\
\hline Corynebacterium diphtheriae & Plectasin (Pseudoplectania nigrella) & $\mathrm{MIC}=8 \mathrm{mg} / \mathrm{L}$ & [63] \\
\hline Corynebacterium jeikeium & Plectasin (Pseudoplectania nigrella) & $\mathrm{MIC}=2 \mathrm{mg} / \mathrm{L}$ & [63] \\
\hline Corynebacterium lilium & $\begin{array}{l}\text { Peptaibol Boletusin, Peptaibol Chrysospermin } 3 \text { and Peptaibol Chrysospermin } 5 \\
\text { (Boletus spp.) }\end{array}$ & $\mathrm{IZD}=23-25 \mathrm{~mm}$ & [64] \\
\hline Enterococcus faecalis & $\begin{array}{l}\text { 1a, 1b and 1c (Albatrellus flettii); } 2 \text { (Jahnoporus hirtus); Plectasin (Pseudoplectania ni- } \\
\text { grella) }\end{array}$ & $\mathrm{MIC}=0.5 \mu \mathrm{g} / \mathrm{mL}-\geq 128 \mathrm{mg} / \mathrm{L}$ & {$[56,63]$} \\
\hline Enterococcus faecium; VREF & Plectasin (Pseudoplectania nigrella) & $\mathrm{MIC}=32-64 \mathrm{mg} / \mathrm{L}$ & [63] \\
\hline Micrococcus flavus & 5a, b (Ganoderma pfeifferi) & $I Z D=25-26 \mathrm{~mm}$ & [57] \\
\hline Staphylococcus aureus & $\begin{array}{l}\text { Peptaibol Boletusin, Peptaibol Chrysospermin } 3 \text { and Peptaibol Chrysospermin } 5 \\
\text { (Boletus spp.); Proteins (Cordyceps sinensis); 6-Methylxanthopurpurin-3-O-methyl } \\
\text { ether (7), (1S,3S)-Austrocortilutein (8a), (1S,3R)- Austrocortilutein (8b), (1S,3S)- } \\
\text { Austrocortirubin (8c) and Torosachrysone (8 d) (Cortinarius basirubencens); Physcion } \\
\text { (9a), Erythroglaucin (9b) and Emodin (9c) (Cortinarius sp.); 4a-d (Flammulina velu- } \\
\text { tipes M); 5a, b (Ganoderma pfeifferi); } \mathbf{3} \text { (Lentinus edodes M); Ribonuclease (Pleurotus } \\
\text { sajor-caju); Plectasin (Pseudoplectania nigrella);Fraction B (Pycnoporus sanguineus); } \\
\text { Coloratin A (10) (Xylaria intracolarata) }\end{array}$ & $\begin{array}{l}\mathrm{IZD}=12-24 \mathrm{~mm} \\
\mathrm{MIC}=0.156 \mathrm{mg} / \mathrm{L}-50000 \mathrm{~g} / \mathrm{L} \\
\mathrm{IC} C_{50}=0.7->50 \mu \mathrm{g} / \mathrm{mL} \\
\mathrm{IC} C_{50}=34 \pm 4 \mu \mathrm{M}\end{array}$ & $\begin{array}{l}{[10,42} \\
57-64]\end{array}$ \\
\hline MRSA & Plectasin (Pseudoplectania nigrella); & $\mathrm{MIC}=32 \mathrm{mg} / \mathrm{L}$ & [63] \\
\hline $\begin{array}{l}\text { Staphylococcus epidermidis; } \\
\text { MRSE }\end{array}$ & Plectasin (Pseudoplectania nigrella) & $\mathrm{MIC}=8 \mathrm{mg} / \mathrm{L}$ & [63] \\
\hline Streptococcus sp. & Peptaibol Chrysospermin 3 (Boletus spp.) & $\mathrm{IZD}=9 \mathrm{~mm}$ & [60] \\
\hline Streptococcus faecalis & 3 (Lentinus edodes M.) & $\mathrm{IZD}=13 \mathrm{~mm}$ & [59] \\
\hline Streptococcus group A, B, C, G & Fraction B (Pycnoporus sanguineus) & $\mathrm{MIC}=0.019-0.039 \mathrm{mg} / \mathrm{mL}$ & [42] \\
\hline $\begin{array}{l}\text { Streptococcus pneumonia; } \\
\text { PRSP }\end{array}$ & Plectasin (Pseudoplectania nigrella) & $\mathrm{MIC}=0.5 \mathrm{mg} / \mathrm{L}$ & [63] \\
\hline $\begin{array}{l}\text { Streptococcus pyogenes; } \\
\text { ERSP }\end{array}$ & Plectasin (Pseudoplectania nigrella) & $\mathrm{MIC}=0.125 \mathrm{mg} / \mathrm{L}$ & [63] \\
\hline
\end{tabular}

M - mycelium, the other samples refer to the fruiting body. The antimicrobial activity is expressed in MIC (minimal inhibitory concentrations), IZD (internal zone diameter), or IC ${ }_{50}$ (concentrations inhibiting $50 \%$ of the growth) values. VREF - vancomycin-resistant Enterococcus faecium; MRSA - methicillin-resistant Staphylococcus aureus; MRSE - methicillin-resistant Staphylococcus epidermidis; PRSP - penicillin-resistant Streptococcus pneumonia; ERSP - erythromycin- resistant Streptococcus pyogenes

bacteria tested, including Bacillus subtilis, Bacillus cereus, Micrococcus luteus, and Micrococcus flavus.

The Lepista nuda methanolic extract had a good action on grampositive bacteria, more specifically on Bacillus cereus, Bacillus subtilis, and Staphylococcus aureus [37,49].

Ishikawa et al. reported the inhibitory activity of Lentinus edodes ethyl acetate extract against Bacillus cereus, Bacillus subtilis, Staphylococcus aureus, and Staphylococcus epidermidis [11]. This mushroom (aqueous extract) as well as the $n$ - $\mathrm{BuOH}$ fraction of the Phellinus linteus methanol extract demonstrated good activity against MRSA [50,51]. Furthermore, Streptococcus pyogenes was very sensitive to the Lentinus edodes chloroform extract [52]. The ability of $L$. edodes extracts to improve oral health has also been extensively researched, since it showed a strong bactericidal effect upon Streptococcus mutans, which is strongly implicated in dental caries and tooth decay $[53,54]$.

The mycelium of Leucopaxillus giganteus (methanolic extract) presented antimicrobial capacity, inhibiting only gram-positive bacteria and, in decreasing order, Staphylococcus aureus $>$ Bacillus cereus $>$ Bacillus subtilis [55]. The authors stated that the most promising nitrogen source to produce mushrooms with an increased content in bioactive compounds that inhibit gram-positive bacteria growth was $\left(\mathrm{NH}_{4}\right)_{2} \mathrm{HPO}_{4}$.
The methanolic extracts of Phellinus rimosus and Navesporus floccosa showed moderate inhibition of Bacillus subtilis and Staphylococcus aureus [40].

Pleurotus ostreatus and Meripilus giganteus showed broad-spectrum antimicrobial activity. The maximum effect was shown by the ethanolic extracts of Pleurotus ostreatus against Sarcina lutea [35].

The ether extract of Pleurotus sajor-caju showed high antibacterial activity against Staphylococcus aureus, whereas Staphylococcus epidermidis showed high sensitivity for the ethanol extract [33].

Overall, it should be pointed out that the most susceptible grampositive bacteria to mushroom inhibitory action are Staphylococos aureus, Bacillus cereus, and Bacillus subtilis. Agaricus bisporus [15,32,33], Agaricus bitorquis [15], Boletus edulis [31,32], Cantharellus cibarius [31,32,37], Lentinus edodes [11,50,54], and different Cortinarius sp. [10] seem to be a good option to inhibit Staphylococos aureus, and in some cases, Bacillus cereus and Bacillus subtilis. Studies with microorganisms related to nosocomial infections and multiresistance cases such as Enterococcus faecalis, Enterococcus faecium, and MRSA are scarce. Nevertheless, in the few studies available, Lentinus edodes [50] was reported to inhibit Enterococcus faecalis, Enterococcus faecium, and MRSA. The latter 
microorganism was also inhibited by Phellinus linteus [51] and Pleurotus ostreatus [50]. It is important to develop new studies with different mushroom species and, moreover, with these microorganisms that are so problematic to human health.

\section{Antimicrobial compounds from mushrooms}

Most studies on mushrooms with antibacterial activity describe the action of its extracts without identifying the compounds responsible for this activity. However, some compounds have been described as active against gram-positive bacteria ( 0 Table 2 ). Five of these compounds are terpenes. Confluentin (1a), grifolin (1b), and neogrifolin (1c) from Albatrellus fletti showed activity against Bacillus cereus and Enterococcus faecalis. The best result was for Enterococcus faecalis (MIC 0.5 to $1.0 \mathrm{mg} / \mathrm{mL}$ ) [56]. Ganomycin A and B (5 a, b), isolated from Ganoderma pfeifferi, showed activity against Bacillus subtilis, Micrococcus flavus, and Staphylococcus aureus (15-25 mm zones of inhibition at a concentration of $250 \mu \mathrm{g} / \mathrm{mL}$ [57].

A steroid, 3,11-dioxolanosta-8,24(Z)-diene-26-oic acid (2), was isolated from the Jahnoporus hirtus mushroom and revealed activity against Bacillus cereus and Enterococcus faecalis [56].

Four sesquiterpenes with antimicrobial activity were described. The enokipodins A, B, C, and D (4a-d), isolated from the mycelium of Flammulina velutipes, with activity against Bacillus subtilis, but only enokipodins A and C showed activity against Staphylococcus aureus [58].

Oxalic acid (3), an organic acid, isolated from the mycelium of Lentinus edodes, showed activity against Bacillus cereus, Staphylococcus aureus, and Streptococcus faecalis [59].

Coloratin A (10), a benzoic acid derivative isolated from Xylaria intracolarata, inhibited Staphylococcus aureus [60].

Eight compounds anthraquinone derivatives were also reported due to their antibacterial activities. 6-Methylxanthopurpurin-30 -methyl ether (7), (1S,3S)-austrocortilutein (8a), (1S,3R)-austrocortilutein (8b), (1S,3S)-austrocortirubin $(\mathbf{8 c})$, and torosachrysone $(\mathbf{8} \mathbf{d})$, isolated from the mushroom Cortinarius basirubencens, and physcion (9a), erythroglaucin (9b), and emodin (9c), isolated from other species of Cortinarius, were all effective against Staphylococcus aureus [10].

In addition to the LMW compounds already mentioned, several antimicrobial compounds with HMW have also been described, in particular, proteins and peptides.

CSAP (Cordyceps sinensis antibacterial protein-N-terminal sequence ALATQHGAP), isolated from Cordyceps sinensis, showed strong activity against Staphylococcus aureus and poor activity against Bacillus subtilis. However, the antibacterial action of this protein was bacteriostatic [61].

The ribonuclease isolated from Pleurotus sajor-caju showed activity against Staphylococcus aureus, acting on RNA [62].

The peptide plectasin, isolated from Pseudoplectania nigrella, is a macromolecule belonging to the class of defensins, present in animals and plants, which acts at the cell wall, more specifically in the synthesis of peptidoglycan. This peptide showed activity against Bacillus cereus, Bacillus thuringiensis, Corynebacterium diphtheriae, Corynebacterium jeikeium, Enterococcus faecalis, Enterococcus faecium, VREF, Staphylococcus aureus, MRSA, Staphylococcus epidermidis, MRSE, Streptococcus pneumonia, PRSP, and Streptococcus pyogenes. The in vitro action of plectasin against Streptococcus pneumoniae is comparable to the action of penicillin and vancomycin [63].

The peptides peptaibol boletusin, pepteibol chrysospermin 3, and peptaibol chrysospermin 5 (isolated from Boletus spp.) allow for the opening of pores for ion transport, and showed activity against Bacillus subtilis, Corynebacterium lilium, and Staphylococcus aureus. The peptaibol chrysospermin 3 also showed activity against Streptococcus sp. [64].

Fraction B from Pycnoporus sanguineus, obtained by Smânia et al. [42], whose main constituent is a phenoxazin-3-one-type pigment, showed activity against Staphylococcus aureus and Streptococcus A, B, C, and G. Lower values of MIC were obtained against Streptococcus strains.

The mechanisms of action of most of the compounds described above are not available in the literature.

\section{Antimicrobial Activity Against Gram-Negative Bacteria}

$\nabla$

\section{Methodologies}

The same methodologies already described for gram-positive bacteria are also used in the evaluation of mushroom extracts or compounds antimicrobial activity against gram-negative bacteria. The results are presented in 0 Tables $\mathbf{3}$ and $\mathbf{4}$.

\section{Mushroom extracts with antimicrobial activity}

The antimicrobial activity against gram-negative bacteria shown by different mushroom extracts is not so extensive and is shown in $\odot$ Table 3.

The results for Agaricus bisporus are contradictory. Barros et al. [31] and Öztürk et al. [15] found no activity against gram-negative bacteria, while Ozen et al. [32] and Tambeker et al. [33] reported positive activity mainly against Escherichia coli, but also against Pseudomonas aeruginosa, Enterobacter aerogenes, Klebsiella pneumoniae, Proteus vulgaris, Salmonella typhi, and Salmonella typhimurium. However, these divergences may be due to different methods and concentrations used. Agaricus bitorquis methanolic extract had some effects against three of the gramnegative bacteria, namely Yersinia enterocolitica, Klebsiella pneumoniae, and Proteus vulgaris [15]. Agaricus essettei, Agaricus silvicola, Agaricus silvaticus, and Agaricus cf. nigrecentulus did not show any antibacterial activity against gram-negative bacteria $[15,31,34]$.

Ethanolic extracts of Armillaria mellea fruiting bodies revealed better antimicrobial activity than chloroform extracts and mycelium extract upon gram-negative bacteria [35,36].

According to Barros et al. [31,37], Cantharellus cibarius showed no activity against gram-negative bacteria, as opposed to Ozen et al. [32], who reported there was activity against Escherichia coli and Pseudomonas aeruginosa.

Enterobacter aerogenes and Escherichia coli were inhibited by the methanolic extract of Clitocybe alexandri [38]. Clitocybe geotropa chloroform and ethanolic extracts inhibited the growth of all gram-negative bacteria tested, with Proteus vulgaris being the most sensitive [36].

Beatttie et al. [10] reported anti-Pseudomonas aeruginosa activity of the genus Cortinarius and its subgenus, Dermocybe (methanolic extracts). Four species were tested, namely $C$. abnormis, $C$. austroalbidus, C. [D. kula], C. persplendidus, and eleven Cortinarius collection samples not identified to the species level, obtaining $\mathrm{IC}_{50}$ values $\leq 0.09 \mathrm{mg} / \mathrm{mL}$ against $P$. aeruginosa.

The acetone extract from Ganoderma lucidum showed strong antibacterial activity, mainly against Klebsiella pneumonia [39]. Further studies indicate that the antimicrobial combination of $G$. lucidum extracts with chemotherapeutic agents (ampicillin, cefazolin, oxytetracycline, and chloramphenicol) resulted in syner- 


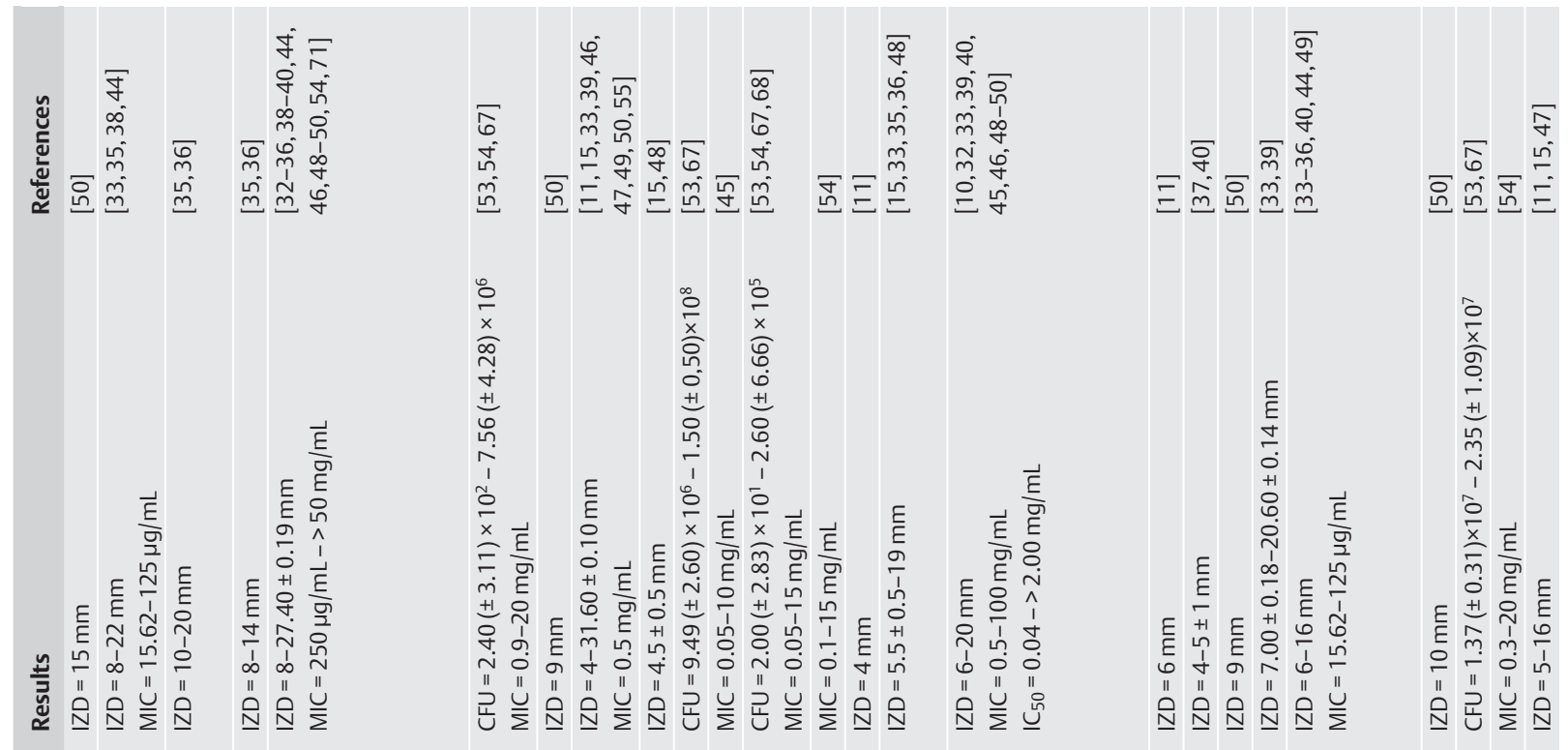

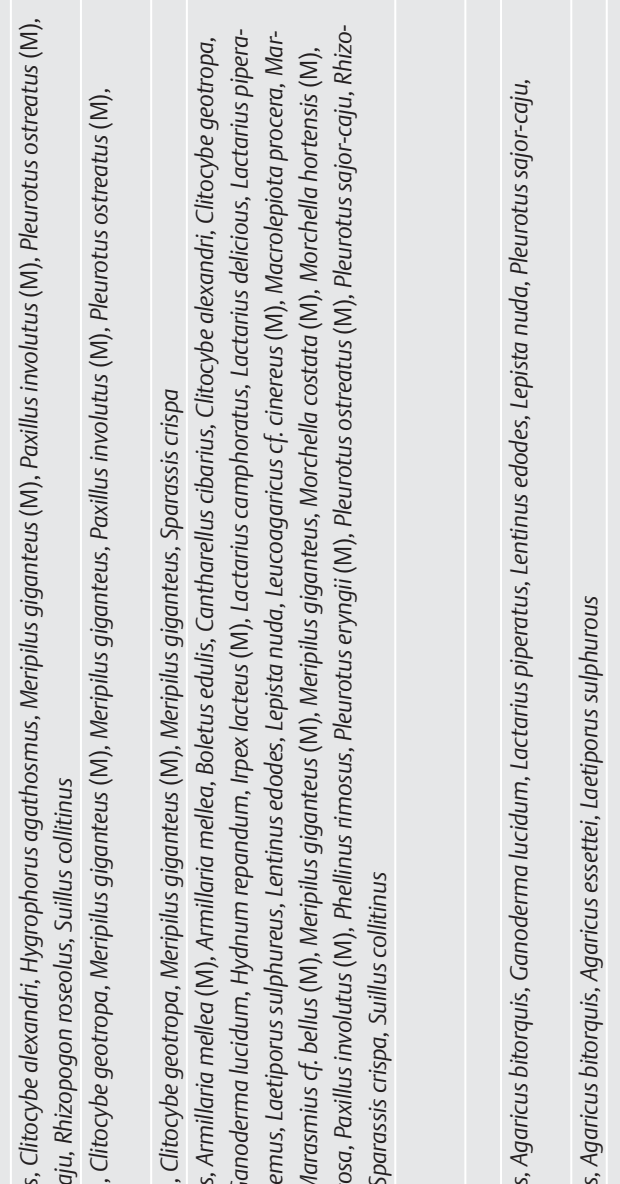

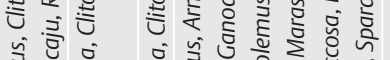

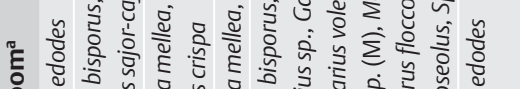





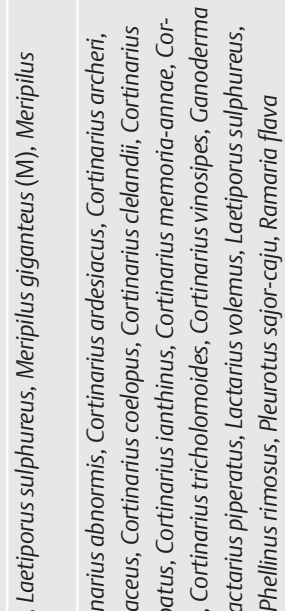

(1)

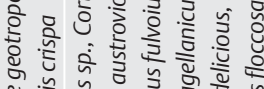



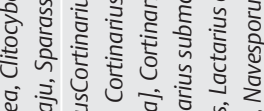

हัँ

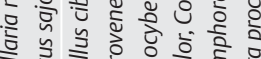

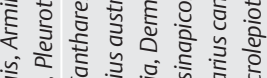


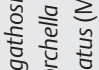

范芒

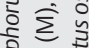



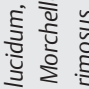

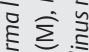

跣 :

है : 仓ै

宽

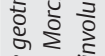

हैำ



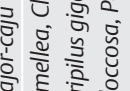

它

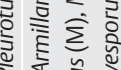

हो

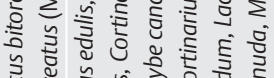

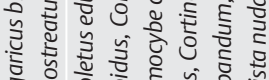

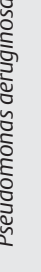


Table 4 Mushroom compounds with antimicrobial activity against gram-negative bacteria.

\begin{tabular}{|c|c|c|c|}
\hline Microorganism & Compound (mushroom) & Results & References \\
\hline Achromobacter xyloxidans & 6 (Leucopaxillus albissimus) & $\mathrm{MIC}=32 \mu \mathrm{g} / \mathrm{mL}$ & {$[69]$} \\
\hline Acinetobacter baumannii & 6 (Leucopaxillus albissimus) & $\mathrm{MIC}=128 \mu \mathrm{g} / \mathrm{mL}$ & [69] \\
\hline Agrobacterium rhizogenes & Protein (Clitocybe sinopica) & $\mathrm{MIC}=0.14 \mu \mathrm{M}$ & [70] \\
\hline Agrobacterium tumefaciens & Protein (Clitocybe sinopica) & $\mathrm{MIC}=0.14 \mu \mathrm{M}$ & [70] \\
\hline Agrobacterium vitis & Protein (Clitocybe sinopica) & $\mathrm{MIC}=0.28 \mu \mathrm{M}$ & [70] \\
\hline Burkholderia cenocepacia & 6 (Leucopaxillus albissimus) & $\mathrm{MIC}=16 \mu \mathrm{g} / \mathrm{mL}$ & [69] \\
\hline Burkholderia cepacia & 6 (Leucopaxillus albissimus) & $\mathrm{MIC}=32 \mu \mathrm{g} / \mathrm{mL}$ & {$[69]$} \\
\hline Burkholderia multivorans & 6 (Leucopaxillus albissimus) & $\mathrm{MIC}=16 \mu \mathrm{g} / \mathrm{mL}$ & [69] \\
\hline Cytophaga johnsonae & 6 (Leucopaxillus albissimus) & $\mathrm{IZD}=16 \mathrm{~mm}$ & [69] \\
\hline Escherichia coli & $\begin{array}{l}\text { Proteins (Cordyceps sinensis); 5a, b (Ganoderma pfeifferi); } \\
\text { Fraction B (Pycnoporus sanguineus); } \mathbf{1 0} \text { (Xylaria intracolarata) }\end{array}$ & $\begin{array}{l}I Z D=4-16 \mathrm{~mm} \\
M I C=0.625 \mathrm{mg} / \mathrm{mL}-100000 \mathrm{~g} / \mathrm{L}\end{array}$ & $\begin{array}{l}{[42,57,60} \\
61]\end{array}$ \\
\hline Klebsiella pneumoniae & $\begin{array}{l}\mathbf{3} \text { (Lentinus edodes M); Fraction B (Pycnoporus sanguineus); } \\
\mathbf{1 0} \text { (Xylaria intracolarata) }\end{array}$ & $\begin{array}{l}\mathrm{IZD}=12-22 \mathrm{~mm} \\
\mathrm{MIC}=0.625 \mathrm{mg} / \mathrm{mL}\end{array}$ & {$[42,59,60]$} \\
\hline Proteus mirabilis & 5a, b (Ganoderma pfeifferi) & $\mathrm{IZD}=15 \mathrm{~mm}$ & [57] \\
\hline Proteus vulgaris & Protein (Cordyceps sinensis); 3 (Lentinus edodes M) & $\begin{array}{l}\mathrm{IZD}=12 \mathrm{~mm} \\
\mathrm{MIC}=75000 \mathrm{~g} / \mathrm{L}\end{array}$ & {$[59,61]$} \\
\hline Pseudomonas aeruginosa & $\begin{array}{l}\text { 7, 8a-8 d (Cortinarius basirubencens); 9a-c (Cortinarius sp.); } \\
\mathbf{3} \text { (Lentinus edodes M); } \mathbf{6} \text { (Leucopaxillus albissimus); } \\
\text { Ribonuclease (Pleurotus sajor-caju); Fraction B (Pycnoporus sanguineus); } \\
\mathbf{1 0} \text { (Xylaria intracolarata) }\end{array}$ & $\begin{array}{l}\mathrm{IZD}=15-16 \mathrm{~mm} \\
\mathrm{MIC}=128 \mu \mathrm{g} / \mathrm{mL}-1.250 \mathrm{mg} / \mathrm{mL} \\
\mathrm{IC}_{50}=1.5->50 \mu \mathrm{g} / \mathrm{mL} \\
\mathrm{IC}_{50}=51 \pm 6 \mu \mathrm{M}\end{array}$ & $\begin{array}{l}{[10,42,59,} \\
62,64,68]\end{array}$ \\
\hline Pseudomonas fluorescens & 3 (Lentinus edodes M); Ribonuclease (Pleurotus sajor-caju) & $\begin{array}{l}\mathrm{IZD}=13 \mathrm{~mm} \\
\mathrm{IC}_{50}=186 \pm 12 \mu \mathrm{M}\end{array}$ & {$[59,62]$} \\
\hline Serratia marcescens & 5a, b (Ganoderma pfeifferi) & $I Z D=15-16 \mathrm{~mm}$ & [57] \\
\hline Salmonella enteritidis & 10 (Xylaria intracolarata) & $\mathrm{IZD}=16 \mathrm{~mm}$ & {$[60]$} \\
\hline Salmonella typhi & Protein (Cordyceps sinensis); Fraction B (Pycnoporus sanguineus) & $\mathrm{MIC}=0.312 \mathrm{mg} / \mathrm{mL}-50000 \mathrm{~g} / \mathrm{L}$ & {$[42,61]$} \\
\hline Stenotrophomonas maltophilia & 6 (Leucopaxillus albissimus) & $\mathrm{MIC}=32 \mu \mathrm{g} / \mathrm{mL}$ & [69] \\
\hline Xanthomonas malvacearum & Protein (Clitocybe sinopica) & $\mathrm{MIC}=0.56 \mu \mathrm{M}$ & [70] \\
\hline Xanthomonas oryzae & Protein (Clitocybe sinopica) & $\mathrm{MIC}=0.56 \mu \mathrm{M}$ & {$[70]$} \\
\hline
\end{tabular}

$\mathrm{M}$ - mycelium, the other samples refer to the fruiting body. The antimicrobial activity is expressed in MIC (minimal inhibitory concentrations), IZD (internal zone diameter), or IC 50 (concentrations inhibiting $50 \%$ of the growth) values

gism or antagonism, with synergism observed when combined with cefazolin against Bacillus subtilis and Klebsiella oxytoca [40, 65].

The mycelium extract from Leucoagaricus cf. cinereus, Marasmius cf. bellus, and Marasmius sp. were capable of inhibiting the growth of Escherichia coli. Within the family Tricholomataceae, species from the genus Marasmius have long been known to produce interesting secondary metabolites [66].

The Hydnum repandum methanolic extract was mainly active against Pseudomonas aeruginosa. Escherichia coli was found to be the most sensitive bacteria to methanolic extracts of Lactarius species [32]. However, no activity of Lactarius delicious against $E$. coli was observed $[45,46]$.

The Laetiporus sulphureus ethanolic extract had a lower antibacterial spectrum against gram-negative bacteria, having no activity against Klebsiella pneumonia [48].

On three occasions, namely with the Pseudomonas sp., Lentinus edodes aqueous extract was significantly more active than ciprofloxacin (positive control), whereby it gave markedly greater zones of inhibition. This result is of important clinical significance, as $P$. aeruginosa is emerging as a major etiological of the nosocomial infection [50]. L. edodes mycelium had no effect on Escherichia coli, Pseudomonas fluorescens, Klebsiella pneumoniae, and Camphylobacter jejuni [52].

Extracts from Lentinus edodes showed a strong bactericidal effect against Prevotella intermedia, which is associated with gingivitis. This mushroom was capable of significantly reducing dental plaque deposition $[53,54,67,68]$.
The Lepista nuda methanolic extract was effective against Escherichia coli and Pseudomonas aeruginosa [49].

Tambeker et al. [33] reported the antimicrobial ability of several extracts of Pleurotus sajor-caju. Escherichia coli, Enterococcus aerogenes, Pseudomonas aeruginosa, and Klebsiella pneumoniae were most sensitive to ethanolic, methanolic, and xylene extracts.

Overall, among the tested gram-negative bacteria, Escherichia coli and Klebsiella pneumoniae are the most susceptible to mushrooms' inhibitory effect. Agaricus bisporus [32,33], Lentinus edodes [50,54], Ganoderma lucidum [39,40], and Lepista nuda [49] seem to have higher antimicrobial activity against those microorganisms. Pseudomonas aeruginosa was inhibited by Clitocybe alexandri [38], Boletus edulis, Cantharellus cibarius [32], Ganoderma lucidum [39], and Cortinarius sp. [10] extracts. Studies with Enterobacter aerogenes and Serratia marcescens are scarce, and due to the importance in the area of multiresistance, they should be carrried out to assess sensibility to extracts from mushroom species.

\section{Antimicrobial compounds from mushrooms}

Some of the compounds previously discussed have also been described for their action against gram-negative bacteria ( $\odot$ Table 4).

Terpenes $\mathbf{5 a}$ and $\mathbf{5 b}$, isolated from Ganoderma pfeifferi, showed moderate activity against Escherichia coli, Proteus mirabilis, and Serratia marcescens [57]. 
The organic acid 3, isolated from the mycelium of Lentinus edodes, showed activity against Klebsiella pneumoniae, Proteus vulgaris, Pseudomonas aeruginosa, and Pseudomonas fluorescens [59]. The benzoic acid derivative 10, isolated from Xylaria intracolarata, showed activity against Escherichia coli, Klebsiella pneumonia, Pseudomonas aeruginosa, and Salmonella enteritidis. For this compound, the highest inhibition (22 $\mathrm{mm}$ ) was found in Klebsiella pneumonia, which is higher than the control (gentamicin, $14 \mathrm{~mm}$ ) [60].

Compounds 7, 8a-d (Cortinarius basirubescens), and 9a-c (Cortinarius spp.) were effective against Pseudomonas aeruginosa [10]. The quinoline 6, isolated from Leucopaxillus albissimus, showed activity against Achromobacter xyloxidans, Acinetobacter baumannii, Burkholderia cenocepacia, Burkholderia cepacia, Burkholderia multivorans, Cytophaga johnsonae, and Pseudomonas aeruginosa. Among the thirteen microorganisms tested, Cytophaga johnsonae was the most strongly inhibited (16 mm) [69].

Some proteins have also been reported against gram-negative bacteria. The protein CSAP, isolated from Cordyceps sinensis and already mentioned above, showed activity against Escherichia coli, Proteus vulgaris, and Salmonella typhi [61], while the protein (N-terminal sequence SVQATVNGDKML) isolated from Clitocybe sinopica was active against Agrobacterium rhizogenes, Agrobacterium tumefaciens, Agrobacterium vitis, Xanthomonas malvacearum, and Xanthomonas oryzae [70].

Ribonuclease (Pleurotus sajor-caju) showed activity against Pseudomonas aeruginosa and Pseudomonas fluorescens, acting at the RNA level [62].

Fraction B (Pycnoporus sanguineus) showed activity against Escherichia coli, Klebsiella pneumoniae, Pseudomonas aeruginosa, and Salmonella typhi [42].

Unfortunatly, the mechanism of action of each one of the isolated compounds is not completly clear and described in the available reports.

\section{Concluding Remarks \\ $\nabla$}

The present review focuses on the antimicrobial effects of mushrooms from all over the world, and their isolated compounds. It will certainly be useful for future scientific studies. Both edible and nonedible mushrooms showed antimicrobial activity against pathogenic microorganisms, including bacteria associated with nosocomial infections (Pseudomonas aeruginosa, Pseudomonas maltophila, Listeria monocytogenes, Staphylococcus aureus, Klebsiella pneumoniae, Morganella morganii, Proteus mirabilis, Serratia marcescens) and multiresistance (MRSA, MRSE, VREF, PRSP, ERSP).

Data available from the literature indicates that mushroom extracts and isolated compounds exhibit higher antimicrobial activity against gram-positive than gram-negative bacteria. Among all the mushrooms, Lentinus edodes is the best-studied species and seems to possess broad antimicrobial action against both gram-positive and gram-negative bacteria. Species from the genera Boletus, Ganoderma, and Lepista appear promising for future studies, if one considers the positive activity and limited number of publications. Considering the low number of studies with individual compounds, Plectasin peptide, isolated from Pseudoplectania nigrella, revealed the highest antimicrobial activity against gram-positive bacteria.

The comparison of the results reported by different authors is difficult, due to the diverse methodologies used to evaluate antimi- crobial activity of mushroom extracts or isolated compounds. Therefore, the standardization of methods and establishment of cut-off values is urgent. The knowledge about the mechanisms of action of different compounds might lead to the discovery of new active principles for antimicrobial activity. Furthermore, the application of cytotoxicity assays is also important to evaluate the effects on humans in the range of the in vitro tested concentrations.

The research on mushrooms is extensive and hundreds of species have demonstrated a broad spectrum of pharmacological activities, including antimicrobial activity. Although there are a number of studies available in the literature, they are almost entirely focused on the screening of antibacterial properties of mushroom extracts. In fact, there is a gap in the identification of the individual compounds responsible for those properties, and only a few low-molecular weight compounds and some peptides and proteins have been described. After elucidation of their mechanism of action, these mushroom metabolites or other related compounds could be used to develop nutraceuticals or drugs effective against pathogenic microorganisms resistant to conventional treatments.

\section{Acknowledgments \\ $\nabla$}

This work was funded by Fundação para a Ciência e a Tecnologia (FCT, Portugal) and COMPETE/QREN/EU (research project PTDC/ AGR-ALI/110062/2009; CIMO strategic project PEst-OE/AGR/ UI0690/2011 and project PEst-OE/EQB/LA0016/2011. It was also supported by CHTAD - Hospital Center of Trás-os-Montes e Alto Douro and Siemens.

\section{Conflict of Interest}

$\nabla$

The authors have no conflicts of interest.

\section{References}

1 Bala N, Aitken EAB, Fechner N, Cusack A, Steadman KJ. Evaluation of antibacterial activity of Australian basidiomycetous macrofungi using a high-throughput 96-well plate assay. Pharm Biol 2011; 49: 1-9

2 Kalač P. Chemical composition and nutritional value of European species of wild growing mushrooms: A review. Food Chem 2009; 113: 916

3 Borchers A, Keen CL, Gershwin ME. Mushrooms, tumors, and immunity: an update. Exp Biol Med 2004; 229: 393-406

4 Lindequist $U$, Niedermeyer THJ, Jülich WD. The pharmacological potential of mushrooms. eCAM 2005; 2: 285-299

5 Poucheret P, Fons F, Rapior S. Biological and pharmacological activity of higher fungi: 20-Year retrospective analysis. Mycologie 2006; 27: 311333

6 Zaidman BZ, Yassin M, Mahajana J, Wasser SP. Medicinal mushroom modulators of molecular targets as cancer therapeutics. Appl Microbiol Biotechnol 2005; 67: 453-468

7 Moradali MF, Mostafavi H, Ghods S, Hedjaroude GA. Immunomodulating and anticancer agents in the realm of macromycetes fungi (macrofungi). Int Immunopharmacol 2007; 7: 701-724

8 Zhang M, Cui SW, Cheung PCK, Wang Q. Antitumor polysaccharides from mushrooms: a review on their isolation process, structural characteristics and antitumor activity. Trends Food Sci Technol 2007; 18: 4-19

9 Wasser SP, Weis AL. Medicinal properties of substances occurring in higher Basidiomycetes mushrooms: Current perspectives (Review). Int J Med Mushrooms 1999; 1: 31-62

10 Beattie KD, Rouf R, Gander L, May TW, Ratkowsky D, Donner CD, Gill M, Grice ID, Tiralongo E. Antibacterial metabolites from Australian macrofungi from the genus Cortinarius. Phytochemistry 2010; 71: 948-955 
11 Ishikawa NK, Kasuya MCM, Vanetti MCD. Antibacterial activity of Lentinula edodes grown in liquid medium. Braz J Microbiol 2001; 32: 206210

12 Shittu OB, Alofe FV, Onawunmi GO, Ogundaini AO, Tiwalade TA. Mycelial growth and antibacterial metabolite production by wild mushrooms. Afr J Biomed Res 2005; 8: 157-162

13 Suay I, Arenal F, Asensio FJ, Basilio A, Cabello MA, Díez MT, García JB, Del Val AG, Gorrochategui J, Hernández P, Peláez F, Vicente MF. Screening of basidiomycetes for antimicrobial activities. Antonie van Leeuwenhoek 2000; 78: 129-139

14 Gonçalves O, Pereira R, Gonçalves F, Mendo S, Coimbra MA, Rocha SM. Evaluation of the mutagenicity of sesquiterpenic compounds and their influence on the susceptibility towards antibiotics of two clinically relevant bacterial strains. Mutat Res 2011; 723: 18-25

15 Öztürk M, Duru ME, Kivrak S, Mercan-Doğan N, Türkoglu A, Özler MA. In vitro antioxidant, anticholinesterase and antimicrobial activity studies on three Agaricus species with fatty acid compositions and iron contents: a comparative study on the three most edible mushrooms. Food Chem Toxicol 2011; 49: 1353-1360

$16 \mathrm{Xu} X$, Yan H, Chen J, Zhang X. Bioactive proteins from mushrooms. Biotechnol Adv 2011; 29: 667-674

17 Fuchs FD. Princípios Gerais do Uso de Antimicrobianos. In: Fuchs F, Wannamacher L, Ferreira M, editors. Farmacologia Clínica - Fundamentos da terapêutica Racional, 3rd edition. Rio de Janeiro: Guanabara Koogan; 2004: 342

18 Tenover FC. Mechanisms of antimicrobial resistance in bacteria. Am J Infect Control 2006; 34 (5 Suppl. 1): S3-S10

19 Koch AL. Bacterial wall as target for attack: past, present, and future research. Clin Microbiol Rev 2003; 16: 673-687

20 Opal SM, Cohen J. Clinical gram-positive sepsis: does it fundamentally differ from gram-negative bacterial sepsis? Crit Care Med 1999; 27: $1608-1616$

21 Ginsburg I. Role of lipoteichoic acid in infection and inflammation. Lancet Infect Dis 2002; 2: 171-179

22 Silveira G, Nome F, Gesser JC, Sá MM, Terenzi H. Estratégias utilizadas no combate a resistência bacteriana. Quím Nova 2006; 29: 3-7

23 Craig WA. Antibacterial therapy. In: Goldman \& Ausiell, editor. Cecil textbook of medicine, 22nd edition. Philadelphia: Saunders; 2004: 1853-1926

24 Harbarth S, Harris AD, Carmeli Y, Samore MH. Parallel analysis of individual and aggregated data on antibiotic exposure and resistance in gram-negative bacilli. Clin Infect Dis 2001; 33: 1462-1468

25 Segal-Maurer S, Urban C, Rahal Jr. JJ. Current perspectives on multidrugresistant bacteria. Epidemiology and control. Infect Dis Clin North Am 1996; 10: 939-957

$26 \mathrm{Kempf}$ M, Rolain JM. Emergence of resistance to carbapenems in Acinetobacter baumannii in Europe: clinical impact and therapeutic options. Int J Antimicrobiol Agents 2012; 39: 105-114

27 WHO. World Health Organization report on infectious diseases 2000 Overcoming antimicrobial resistance. Available at http://www.who. int/infectious-disease-report. Accessed January 21, 2012

28 Peres-Bota D, Rodriguez H, Dimopoulos G, DaRos A, Mélot C, Struelens MJ, Vincent $J L$. Are infections due to resistant pathogens associated with a worse outcome in critically ill patients? J Infect 2003; 47: 307-316

29 Pittet $D$. Infection control and quality health care in the new millennium. Am J Infect Control 2005; 33: 258-267

30 WHO. World Health Organization report - Antimicrobial resistance (AMR). Available at http://www.who.int/mediacentre/news/releases/ 2010/amr_20100820/en/index.html. Accessed January 21, 2012

31 Barros L, Cruz T, Baptista P, Estevinho LM, Ferreira ICFR. Wild and commercial mushrooms as source of nutrients and nutraceuticals. Food Chem Toxicol 2008; 46: 2742-2747

32 Ozen T, Darcan C, Aktop 0, Turkekul I. Screening of antioxidant, antimicrobial activities and chemical contents of edible mushrooms wildly grown in the Black Sea region of Turkey. Comb Chem High Throughput Screen 2011; 14: 72-84

33 Tambekar DH, Sonar TP, Khodke MV, Khante BS. The novel antibacterials from two edible mushrooms: Agaricus bisporus and Pleurotus sajor caju. Int J Pharmacol 2006; 2: 584-587

34 Rosa LH, Machado KMG, Jacob CC, Capelari M, Rosa CA, Zani CL. Screening of Brazilian Basidiomycetes for antimicrobial activity. Mem Inst Oswaldo Cruz 2003; 98: 967-974

35 Kalyoncu F, Oskay M, Salam H, Erdogan TF, Tamer AÜ. Antimicrobial and antioxidant activities of mycelia of 10 wild mushroom species. J Med Food 2010; 13: 415-419
36 Kalyoncu F, Oskay M. Antimicrobial activities of four wild mushroom species collected from Turkey. Proceeding of the 6th International Conference on Mushroom Biology and Mushroom Products, 2008. Krefeld, Germany: J.I. LelleyGAMU GmbH, Institut für Pilzforschung; 2008

37 Barros L, Venturini BA, Baptista P, Estevinho LM, Ferreira ICFR. Chemical composition and biological properties of Portuguese wild mushrooms: a comprehensive study. J Agric Food Chem 2008; 56: 3856-3862

38 Solak MH, Kalmis E, Saglam H, Kalyoncu F. Antimicrobial activity of two wild mushrooms Clitocybe alexandri (Gill.) Konr. and Rhizopogon roseolus (Corda) T.M. Fries collected from Turkey. Phytother Res 2006; 20: 1085-1087

39 Quereshi S, Pandey AK, Sandhu SS. Evaluation of antibacterial activity of different Ganoderma lucidum extracts. J Sci Res 2010; 3: 9-13

40 Sheena N, Ajith TA, Mathew AT, Janardhanan KK. Antibacterial activity of three macrofungi, Ganoderma lucidum, Navesporus floccosa and Phellinus rimosus occurring in South India. Pharm Biol 2003; 41: 564567

41 Gao Y, Tang W, Gao H, Chan E, Lan J, Li X, Zhou S. Antimicrobial activity of the medicinal mushroom Ganoderma. Food Rev Int 2005; 21: 211 229

42 Smânia A, Monache FD, Smânia EFA, Gil ML, Benchetrit LC, Cruz FS. Antibacterial activity of a substance produced by the fungus Pycnoporus sanguineus (Fr.) Murr. J Ethnopharmacol 1995; 45: 177-181

43 Smânia EFA, Smânia A, Loguercio-Leite C, Gil ML. Optimal parameters for cinnabarin synthesis by Pycnoporus sanguineus. J Chem Technol Biotechnol 1997; 70: 57-59

44 Yamac M, Bilgili F. Antimicrobial activities of fruit bodies and/or mycelial cultures of some mushroom isolates. Pharm Biol 2006; 44: 660667

45 Barros L, Calhelha RC, Vaz JA, Ferreira ICFR, Baptista P, Estevinho LM. Antimicrobial activity and bioactive compounds of Portuguese wild edible mushrooms methanolic extracts. Eur Food Res Technol 2007; 225: 151-156

46 Barros L, Baptista P, Estevinho LM, Ferreira ICFR. Effect of fruiting body maturity stage on chemical composition and antimicrobial activity of Lactarius sp. mushrooms. J Agric Food Chem 2007; 55: 8766-8771

47 Gezer K, Duru ME, Kivrak I, Turkoglu A, Mercan N, Turkoglu H, Gulcan S. Free-radical scavenging capacity and antimicrobial activity of wild edible mushroom from Turkey. Afr J Biotechnol 2006; 5: 1924-1928

48 Turkoglu A, Duru ME, Mercan N, Kivrak I, Gezer K. Antioxidant and antimicrobial activities of Laetiporus sulphureus (Bull.) Murrill. Food Chem 2007; 101: 267-273

49 Dulger B, Ergul CC, Gucin F. Antimicrobial activity of the macrofungus Lepista nuda. Fitoterapia 2002; 73: 695-697

50 Hearst R, Nelson D, McCollum G, Millar BC, Maeda Y, Goldsmith CE, Rooney PJ, Loughrey A, Rao JR, Moore JE. An examination of antibacterial and antifungal properties of constituents of Shiitake (Lentinula edodes) and Oyster (Pleurotus ostreatus) mushrooms. Complement Ther Clin Pract 2009; 15: 5-7

51 Hur JM, Yang CH, Han SH, Lee SH, You YO, Park -C, Kim KJ. Antibacterial effect of Phellinus linteus against methicillin-resistant Staphylococcus aureus. Fitoterapia 2004; 75: 603-605

52 Hatvani N. Antibacterial effect of the culture fluid of Lentinus edodes mycelium grown in submerged liquid culture. Int J Antimicrob Agents 2001; 17: 71-74

53 Signoretto C, Burlacchini G, Marchi A, Grillenzoni M, Cavalleri G, Ciric L, Lingström P, Pezzati E, Daglia M, Zaura E, Pratten J, Spratt DA, Wilson M, Canepari P. Testing a low molecular mass fraction of a mushroom (Lentinus edodes) extract formulated as an oral rinse in a cohort of volunteers. J Biomed Biotechnol, advance online publication 2011; :DOI: $10.1155 / 2011 / 857987$

54 Hirasawa M, Shouji N, Neta T, Fukushima K, Takada K. Three kinds of antibacterial substances from Lentinus edodes (Berk.) Sing. (Shiitake, an edible mushroom). Int J Antimicrob Agents 1999; 11: 151-157

55 Barros L, Baptista P, Estevinho LM, Ferreira ICFR. Bioactive properties of the medicinal mushroom Leucopaxillus giganteus mycelium obtained in the presence of different nitrogen sources. Food Chem 2007; 105: 179-186

56 Liu XT, Winkler AL, Schwan WR, Volk TJ, Rott MA, Monte A. Antibacterial compounds from mushrooms I: a lanostane-type triterpene and prenylphenol derivates from Jahnoporus hiritus and Albatrellus flettii and their activities against Bacillus cereus and Enterococcus faecalis. Planta Med 2010; 76: 182-185 
57 Mothana RAA, Jansen R, Jülich WD, Lindequist U. Ganomycins A and B, new antimicrobial Farnesyl hydroquinones from the Basidiomycete Ganoderma pfeifferi. J Nat Prod 2000; 63: 416-418

58 Ishikawa NK, Fukushi Y, Yamaji K, Tahara S, Takahashi K. Antimicrobial cuparene-type sesquiterpenes, enokipodins $C$ and $D$, from a mycelial culture of Flammulina velutipes. J Nat Prod 2001; 64: 932-934

59 Bender S, Dumitrache CN, Backhaus J, Christie G, Cross RF, Lonergan GT, Baker WL. A case for caution in assessing the antibiotic activity of extracts of culinary-medicinal Shiitake mushroom [Lentinus edodes (Berk.) Singer] (Agaricomycetideae). Int J Med Mushrooms 2003; 5: 31-35

60 Quang DN, Bach DD, Hashimoto T, Asakawa Y. Chemical constituents of the Vietnamese inedible mushroom Xylaria intracolorata. Nat Prod Res 2006; 20: 317-321

61 Zheng H, Maoqing Y, Liqiu X, Wenjuan T, Lian L, Guolin Z. Purification and characterization of an antibacterial protein from the cultured mycelia of Cordyceps sinensis. Wuhan Univ J Nat Sci 2006; 11: 709-714

62 Ngai PHK, Ng TB. A ribonuclease with antimicrobial, antimitogenic and antiproliferative activities from the edible mushroom Pleurotus sajorcaju. Peptides 2004; 25: 11-17

63 Mygind PH, Fischer RL, Schnorr KM, Hansen MT, Sönksen CP, Ludvigsen S, Raventós D, Buskov S, Christensen B, De Maria L, Taboureau O, Yaver D, Elvig-Jørgensen SG, Sørensen MV, Christensen BE, Kjærulff S, FrimodtMoller N, Lehrer RI, Zasloff M, Kristensen HH. Plectasin is a peptide antibiotic with therapeutic potential from a saprophytic fungu. Nature 2005; 437: 975-980

64 Lee SJ, Yeo WH, Yun S, Yoo D. Isolation and sequence analysis of new peptaibol, boletusin, from Boletus spp. J Pept Sci 1999; 5: 374-378
65 Yoon SY, Eo SK, Kim YS, Lee CK, Han SS. Antimicrobial activity of Ganoderma lucidum extract alone and in combination with some antibiotics. Arch Pharm Res 1994; 17: 438-442

66 Anke T, Kupka J, Schramm G, Steglich W. Antibiotics from basidiomycetes. X. Scorodonin, a new antibacterial and antifungal metabolite from Marasmius scorononius (Fr.). J Antibiot 1980; 33: 463-467

67 Ciric L, Tymon A, Zaura E, Lingström P, Stauder M, Papetti A, Signoretto C, Pratten J, Wilson M, Spratt D. In vitro assessment of Shiitake mushroom (Lentinula edodes) extract for its antigingivitis activity. J Biomed Biotechnol, advance online publication 2011; DOI: 10.1155/2011/507908

68 Signoretto C, Marchi A, Bertoncelli A, Burlacchini G, Tessarolo F, Caola I, Pezzati E, Zaura E, Papetti A, Lingström P, Pratten J, Spratt DA, Wilson M, Canepari P. Effects of mushroom and chicory extracts on the physiology and shape of Prevotella intermedia, a periodontopathogenic bacterium. J Biomed Biotechnol, advance online publication 2011; DOI: $10.1155 / 2011 / 635348$

69 SchwanWR, Dunek C, Gebhardt M, Engelbrecht K, Klett T, Monte A, Toce J, Rott M, Volk TJ, LiPuma JJ, Liu XT, McKelvey R. Screening a mushroom extract library for activity against Acinetobacter baumannii and Burkholderia cepacia and the identification of a compound with anti-Burkholderia activity. Ann Clin Microb Antimicrob 2010; 9: 4

70 Zheng S, Liu Q Zhang G, Wang H, Ng TB. Purification and characterization of an antibacterial protein from dried fruiting bodies of the wild mushroom Clitocybe sinopica. Acta Biochim Pol 2010; 51: 43-48

71 Nicholas GM, Blunt JW, Munro MHG. Cortamidine oxide, a novel disulfide metabolite from the New Zealand basidiomycete (mushroom) Cortinarius species. J Nat Prod 2001; 64: 341-344 